\title{
Ways to achieve universal access to sustainable electricity in Southeast Asia
}

\author{
Farhad Taghizadeh-Hesary ${ }^{1}$ (D) $\cdot$ Ehsan Rasoulinezhad ${ }^{2} \cdot$ Han $^{\text {Phoumin }}{ }^{3}$
}

Received: 11 October 2021 / Accepted: 2 February 2022 / Published online: 25 February 2022

(C) The Author(s), under exclusive licence to Springer Science+Business Media, LLC, part of Springer Nature 2022

\begin{abstract}
This paper proposes a multidimensional dependent variable, namely the Green Power Index, as an appropriate proxy for a sustainable power market and assesses its determinants. For this purpose, we apply the product lifecycle management estimator with the panel Autoregressive Distributive Lag framework for the annual data of 2000-2019 of nine Southeast Asian countries. The findings revealed that Southeast Asian nations consider the following as appropriate accelerators to a sustainable power market in the short and long run: economic growth, improved foreign direct investment inflow, increased share of research and development, governance, and privatisation. Conversely, an increase in the price of electricity may slow it down. Empirical findings show that major policy implications include implementing electricity tariff classifications, accelerating economic recovery in the post-COVID-19, boosting bilateral trade and investments and partnerships among Southeast Asian countries and other economic powers in Asia and others.
\end{abstract}

Keywords Electricity market · Sustainability · The Green Power Index · ASEAN · Southeast Asia

\section{Introduction and background}

In recent decades, scholars have debated over reform in electricity markets due to factors such as environmental pollution and the security of electricity supply. Increasing market efficiency and developing common access to favorable market-based electricity tariffs is a complicated challenge for public policy. While

Farhad Taghizadeh-Hesary

farhad@tsc.u-tokai.ac.jp

1 Tokai University, Tokyo, Japan

2 Faculty of World Studies, University of Tehran, Tehran, Iran

3 Economic Research Institute for ASEAN and East Asia, Jakarta, Indonesia 
electricity market reforms may help countries pivot to clean energy systems and achieve wider access to more affordable electricity, obstacles such as the coronavirus disease (COVID-19) pandemic (Norouzi et al. 2020), lack of project capital (Nelson 2020), and outdated market regulations (Zsiboracs et al. 2020) slow the pace of reforms in power markets. According to the data of BP (2020), though gas and coal were two major sources of electricity generation in 1985-2019, the efforts of countries to shift from fossil fuels to green energy are apparent. The United Kingdom pioneered giant electricity reform towards a liberal electricity market in 1988 (Tsay and Chen 2019). In the 1980s, Chile reformed its power market to decrease public debt and motivate private financing, followed by Argentina, Colombia, and Peru in the early 1990s (Dussan 1996). Since the mid-1990s, developing nations in Asia have initiated plans and policies for their power industries. For instance, Turkey has carried out different reforms since 2001 towards a liberal and organised power market (Senerdem and Akkemik 2020). Singapore was the pioneer in Southeast Asia to establish and develop a competitive electricity market since the mid of 1990 s, highlighting the privatisation and corporatisation of the power industry. The Philippines followed Singapore and launched the Wholesale Electricity Spot Market. However, the results of these reforms were not significant and efficient (Sharma 2005). The lack of capital, slow deployment of technology, and low private sector participation are the main reasons for the inefficiency of reforms in the region (e.g., see Sarangi et al. 2019; Delina 2021; Mohsin et al. 2021).

According to an International Energy Agency (IEA) report in 2020, Southeast Asia is one of the fastest-growing regions globally in terms of power demand. Malaysia, Thailand, Viet Nam, and Indonesia make up over $80 \%$ of the total electricity demand in the region (IEA 2020). This region defined its 2030 target to universal access and aims to double its capacity to generate power by 2040 (Weatherby 2020). While millions of people have gained access to electricity since 2000 , a large portion of the population in the region still has problems accessing electricity today (IEA 2019). Achieving universal access to electricity and increasing electricity market efficiency is crucial to economic growth. However, policymakers must achieve a green power sector and reduce its reliance on fuel while doing so. In recent decades, some economies in Southeast Asia have addressed the reforms in their electricity market. For instance, Malaysia reformed the Malaysia Electricity Supply Industry in 1992. Singapore started the policy of electricity market liberalisation in 1995, and Taiwan has issued electricity market reforms policies since 1990 (Tsay and Chen 2019).

The need for electricity market reforms in Southeast Asia and the factors affecting the pace of reforms motivates us to do this research. In this study, we assessed the impact of three groups of variables-macroeconomic variables, electricity tariffs, and governance - on the Green Power Index (GPI) of the economies of the Association of Southeast Asian Nations (ASEAN). The GPI, as the dependent variable, was constructed in this study and is a novelty of our research. The index comprised the electrification ratio, the share of renewable energy in total power generation, and the level of energy-related carbon dioxide $\left(\mathrm{CO}_{2}\right)$ emission. The explanatory variables included gross domestic product (GDP) in real terms, foreign direct investment 
(FDI), research and development (R\&D) expenditures in the energy sector, electricity tariffs, privatisation of the power sector, deregulation of the electricity sector, and green policies.

Earlier studies by Kundu and Mishara (2011), Urpelainen and Yang (2019), and Zheng (2021) assessed the impacts of these explanatory variables on electrification, $\mathrm{CO}_{2}$ emission, and renewable energy deployment for other regions. However, to the best of the authors' knowledge, no assessment has been done on the impact of these explanatory variables on the GPI. Hence, our research has two contributions to existing literature. First, we define a new multidimensional GPI. Second, this is the first study on ASEAN where the results of our research can help members achieve sustainable power markets.

The research structure has different sections. Section 2 provides a brief literature review to show the literature gap that this paper aims to fill. Section 3 presents the data description and model specification. Section 4 discusses the empirical results. The last section provides concluding remarks and policy implications.

\section{Literature review}

\subsection{Barriers for accessing sustainable electricity market}

The need for countries to transition to sustainable electricity markets has drawn the attention of scholars. As a pioneer study, Dussan (1996) addressed the electric market reform as a tool to increase private sector participation. Sarangi et al. (2019), Nasr Esfahani et al. (2021), and Hao et al. (2021) addressed the reforms in electricity markets to reach sustainable energy security in developing nations. Besant-Jones (2006) believes that service quality, green economic growth, and government fiscal level drive power market reform in developing economies. Brown et al. (2017) argued that revising power markets through various technology reforms and policies, infrastructure, pricing, and fiscal policies lead to efficient electricity tariffs. Xu and Guo (2017) highlighted the role of electric power market reforms to eliminate monopolies in developing nations. Defeuilley (2019) discussed that country alliances to combat environmental pollution, and climate change will lead to greener electricity. Similarly, Akrami et al. (2019) revealed that many countries need to adjust existing electricity market reforms that cause uncertainty and variability in the operation and supply of power. Furthermore, Yin et al. (2019) revealed that reforms to liberalise the electricity market are vital for developing nations. Senderdem and Akkemik (2020) also highlighted that reforms to liberalise and integrate the public and private sectors are adequate policies towards an efficient power market. Dodd et al. (2020) expressed that reforms benefit both the demand and supply sides. Mier and Weissbart (2020) proved that the current power markets are inefficient and urged countries to aim for decarbonisation targets. Guo et al. (2020) studied China's power market reform efficiency and concluded that the reform is a complicated matter with various factors affecting results. In another study, Sorknaes et al. (2020) highlighted different macroecoonmic barriers to reaching a smart energy market. They argued that electricity markets need some policies to absorb FDI and private investors to increase the contributions of green energy sources in power plants. As 
a significant barrier, the lack of sufficient capital to finance green power projects has been drawn attention by previous studies like Taghizadeh-Hesary and Yoshino, (2019), Nelson (2020), Tsao et al. (2021), Anh Tu and Rasoulinezhad (2021), Taghizadeh-Hesary et al. (2021), Tran (2021). Since the return on investment in green energy schemes is not attractive and high, private sector investors are not easily willing to participate in such schemes. This is one of the obstacles to developing electricity generation from green energy sources.

\subsection{Solutions}

Many scholars have considered different aspects and characteristics of electricity market solutions. Poudineh et al. (2020) argue that reforms in the power market varies with each country and depend on various factors. One of the major factors in electricity market reform is privatisation. Pineal (2002) used the case of Cameroon to highlight privatisation as an appropriate solution. The private sector can bring more capital to the power industry, which needs more efficient technology and production patterns. This argument is in line with Kundu and Mishara (2011) results in the case of power reform in Orissa, India. In other studies, Urpelainen and Yang (2019) also expressed that liberalisation can accelerate privatisation to help countries boost reforms for reliable supply in the electricity market. Another influential factor in electricity market reform is R\&D expenditure. Sirin and Erdogen (2013) indicated that one of the most critical electricity sector challenges is the deployment of new technologies, which depends on the amount of R\&D. This relationship was proved by other scholars such as Pollitt (2019). Due to the lack of private capital in developing countries, like most countries in Southeast Asia, FDI flows play a significant role in the implications of electricity market reform. Xuegong et al. (2013) expressed that FDI may encourage the private sector to participate in the electricity market, which would boost reform in the market. Other scholars such as Zheng (2021) have shown the significant impact of FDI on the electricity market.

\subsection{Literature gap}

According to the literature mentioned above, evaluating macroeconomic variables' impacts on the sustainable power market is valuable and brings insights for policymakers and scholars worldwide. Based on the authors' knowledge, there has not been any serious academic study focusing on the impacts of FDI, privatisation, and R\&D expenditure on electricity markets in Southeast Asia. Therefore, the paper seeks to fill this literature gap. 


\section{Data and methodology}

\subsection{Theoretical background}

To evaluate the sustainable power market, the paper considers a top-down model in a power generation market, which can be used to interpret a market based on macroeconomic theory and variables (Cieplinski et al. 2021). The top-down model in an optimization-based approach in the format of the Bellman equation (Eq. 1) can be written as follows:

$$
V\left(x_{0}\right)=\max _{a_{0}}\left[F\left(x_{0}, \alpha_{0}\right)+\beta V\left(x_{1}\right)\right]
$$

where the best possible value of the objective is represented by V. The first-order condition for Eq. (1) can be conducted and result as Eq. (2):

$$
\frac{\vartheta}{\vartheta a_{0}}\left(V\left(x_{0}\right)=\max _{a_{0}}\left[F\left(x_{0}, \alpha_{0}\right)+\beta V\left(x_{1}\right)\right]\right)
$$

Under the envelope condition, the derivative of the value function is as Eq. 3:

$$
\frac{\vartheta}{\vartheta x_{0}}\left(V\left(x_{0}\right)=\max _{a_{0}}\left[F\left(x_{0}, \alpha_{0}\right)+\beta V\left(x_{1}\right)\right]\right)
$$

It can be concluded that optimizing a sustainable electricity market depends on various economic variables $(\mathrm{X} 1, \mathrm{X} 2)$, which can positively or negatively impact the development of a sustainable electricity market in a country. The related variables to the sustainable electricity market have been chosen based on the existing literature such as Pineal (2002), Kundu and Mishara (2011), Urpelainen and Yang (2019), Pollitt (2019), and Zheng (2011).

\subsection{Data description}

The main objective of this paper is to find the relationship between sustainable power markets and macroeconomic variables in Southeast Asian countries. This paper proposes a multidimensional dependent variable, namely the GPI, as an appropriate proxy for a sustainable power market. To develop the GPI, we will employ a statistical analysis technique: the principal component analysis (PCA). The PCA is a standard data reduction technique that entails extracting data, removing redundant information, highlighting hidden features, and visualizing the main relationships between observations. This analysis is a technique for simplifying a data set by reducing multidimensional data sets to lower dimensions for analysis. The three dependent variables shown in the first equation (Eq. 4) below will be used to shape one dependent component (GPI) through the PCA.

$$
G P I=f(E L E C T, C A R B O N, R E)
$$


Equation 4 shows that the GPI is a function of three variables: ELECT (Electricification ratio), $C A R B O N$ (Energy-related carbon dioxide emission), $R E$ (Share of renewable energy in the total power generation). However, we need to ensure the reliability of using the PCA to efficiently factorise the three variables. Hence, we run the Kaiser-Meyer-Olkin (KMO) measure of sampling adequacy.

Furthermore, explanatory variables in our model are classified into four categories: macroeconomic variables, price level, governance in relation to the power market, and general governance indicator. In following Balza et al. (2013), we selected privatisation in the power market as a proxy. Further, the general governance indicator is a function of three separate governance variables: political stability, regulatory quality, and government effectiveness from the Worldwide Governance Indicators in variables as listed in Table 1.

\subsection{Empirical model specification}

The primary econometric equation of our model is considered as Eq. 5.

$$
G P I_{i t}=\alpha_{0}+\alpha_{1} G D P_{i t}+\alpha_{2} F D I_{i t}+\alpha_{3} R D_{i t}+\alpha_{4} T A R_{i t}+\alpha_{5} P R I V_{i t}+\alpha_{6} G I_{i t}+\alpha_{i t}+\varepsilon_{t}
$$

In Eq. 5, GPI and GI are the two multidimensional variables representing the Green Power Index and the Governance Index that will be created using PCA technique. To explore how the GPI is determined in Southeast Asian countries, we will carry out a panel data estimation using Eq. 5 by employing data over 2000-2019 in nine countries: Cambodia, Indonesia, the Lao People's Democratic Republic (Lao PDR), Malaysia, the Republic of the Union of Myanmar (henceforth, Myanmar), the Philippines, Singapore, Thailand, and Viet Nam. The time-series data will be gathered from the World Bank database, The Purnomo Yusgiantoro Center (PYC) Data Center, the Association of Southeast Asian Nations (ASEAN) Centre for Energy, Private Participation in Infrastructure database, Worldwide Governance Indicators report, BP (British Petroleum) statistical energy review 2020, and energy authorities in each country like the Federation of Malaysian Manufacturers and the Council for the Development of Cambodia.

Regarding estimation strategy, since T as the time period (2000-2019) is more than the number of cross-sections (nine countries), the appropriate econometric technique is the panel ARDL approach proposed by Pesaran and Smith (1995), including the mean group (MG) estimator, pooled mean group (PMG), and dynamic fixed effect (DFE) estimators. Equation 5 in the form of the ARDL approach can be written as Eq. 6:

$$
\Delta \ln G P I_{i . t}=\sum_{j=1}^{p-1} \beta_{j}^{i} \Delta \ln G P I_{i . t-j}+\sum_{j=0}^{q-1} \rho_{j}^{i} \ln X_{i . t-j}+\delta^{i}\left[\ln G P I_{i . t-1}-\left\{\theta_{0}^{i}+\theta_{1}^{i} X_{i . t-1}\right\}\right]+\mu_{i t}
$$

where GPI indicates Green Power Index, X represents the vector set of all regressors (i.e., macroeconomic variables: GDP, FDI, and R\&D expenditure in the energy sector), average electricity tariff, and privatisation of the power sector and governance 


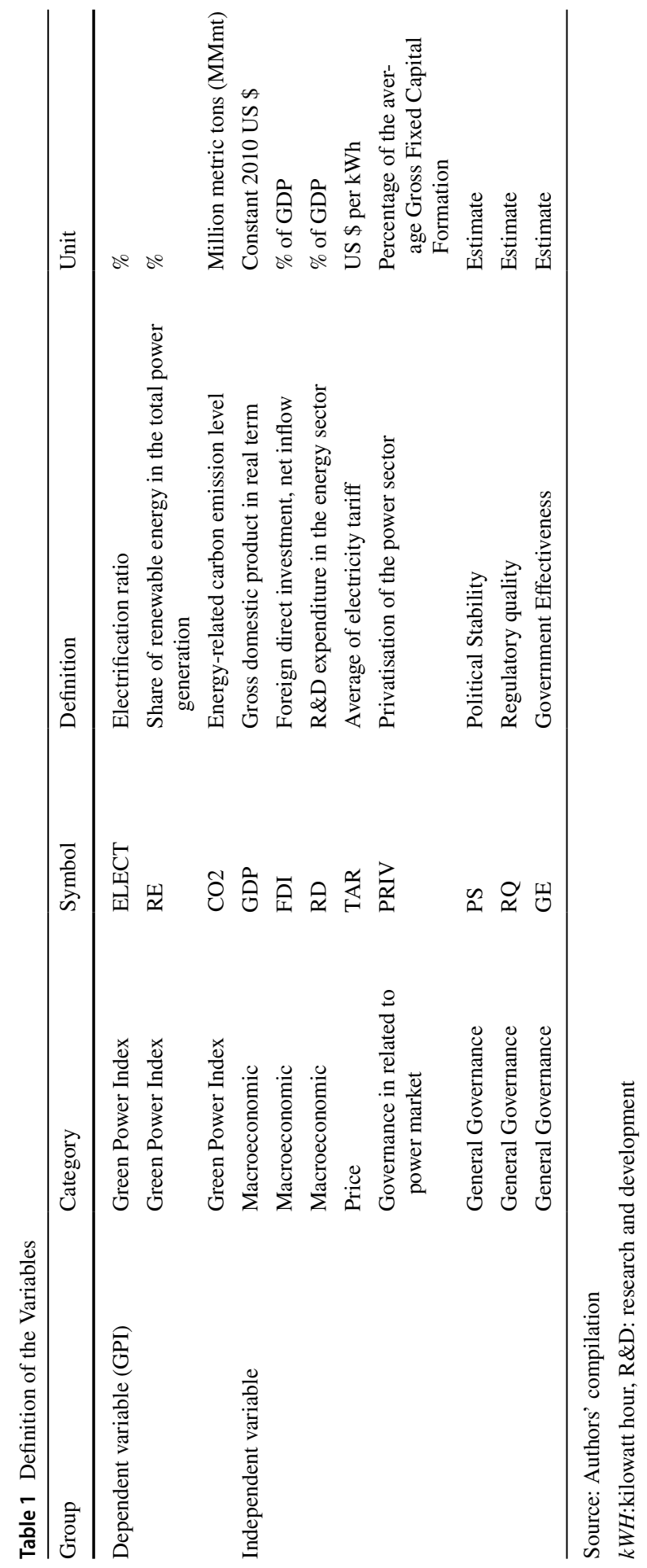


index. Furthermore, $\beta$ and $\rho$ are the short-run coefficients of lagged GPI and regressors, respectively, while $\theta$ and $\delta$ denote the long-run coefficients and the coefficient of the speed of adjustment to the long-run equilibrium. Finally, $i$ and t represent a country from Southeast Asia and the years 2000-2019.

Econometrically, MG estimates the coefficients of each country and considers the mean of all coefficients of the group of countries, while the PMG allows short-run coefficients and intercepts to be dissimilar among cross-sections. The DFE estimator constrains both long- and short-run coefficients to be constant across countries in the panel group. Following Lau et al. (2019) and Smolovic et al. (2020), who declared that the PMG estimator performs better than the other two estimators and is robust to outliers and lag orders, we run the Hauman test to recognize the significance of the PMG estimator rather than two estimators of MG and DFE in our research. Then, we carry out the cross-sectional dependence of Breusch-Pagan LM (Lagrange Multiplier), Pesaran Scaled LM and Pesaran CD (cross-sectional dependence) to check the existence of cross-sectional dependency among sample countries.

Next, the panel unit root tests, namely Levin et al. (2002), Im et al. (2003), Breitung (2001) as first-generation unit tests and the cross-sectionally augmented IPS (Im, Pesaran and Shin test) of Pesaran (2007) are employed to explore the stationary level of variables. If prior tests confirm the integration among variables, the investigation of the long-run relationship between series is conducted through three tests: Pedroni (1999) and Kao (1999) as the first generation of cointegration test and Westerlund (2007) as the second generation of cointegration test based on structural dynamics.

Once the series are found to be cointegrated in the long-run, we can seek the signs and magnitudes of long-run relationship between variables. To this end, a PMG estimation through the ARDL framework is performed and two other estimators of MG and DFE are used to explore the reliability of our empirical findings.

The conceptual framework of methodological procedure can be shown in Fig. 1 as follows.

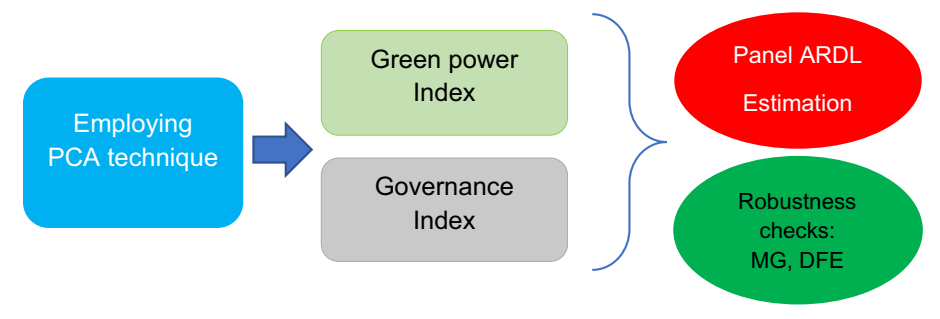

Note: $A R D L=$ Autoregressive Distributed Lag; $P C A=$ principal component analysis; $M G=$ mean group estimator; DFE= dynamic fixed effect estimator

Fig. 1 Conceptual framework of research. Source: Authors' illustration 
(a) Green Power Index

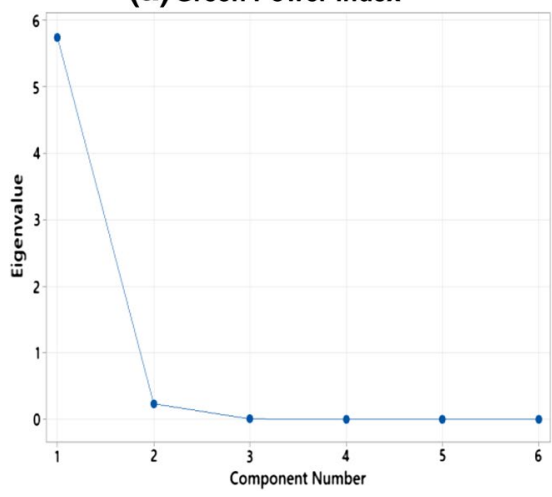

(b) Governance Index

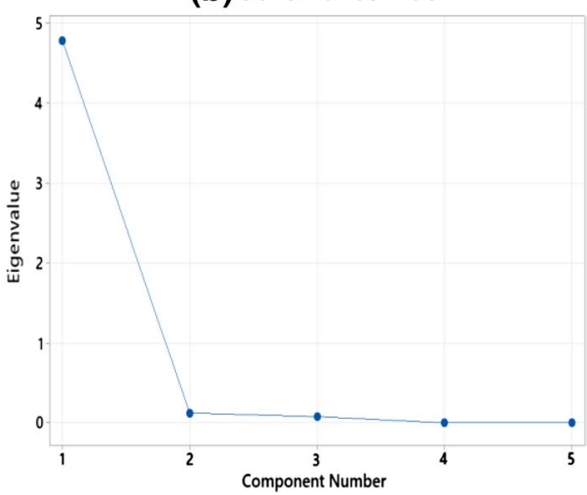

Fig. 2 Screen plot, PCA Technique. Source: Authors' compilation from Minitab 20.2

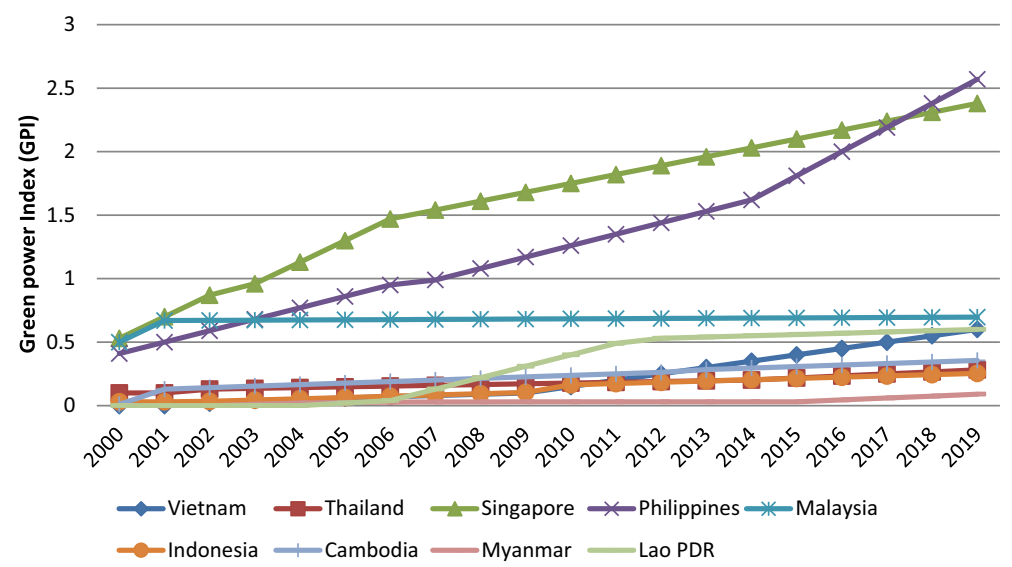

Fig. 3 Green power index, Southeast Asian Countries, 2000-2019. Lao PDR = the Lao People's Democratic Republic, Source: Authors' compilation from Minitab 20.2

\section{Empirical results}

\subsection{Applying the principal component analysis technique}

For the first stage, we need to create the multidimensional variable of the Green Power Index (GPI) and governance indicator (GI) using the principal component analysis (PCA) technique. Prior to running the PCA, we verify that the data of variables can support the use of the PCA technique. The observed KMO statistics is 0.661 and 0.692 , meaning that the samples are adequate for PCA. Performing the PCA technique for three variables-electrification ratio, the share of renewable energy in the total power generation, and energy-related carbon emission levelonly one component is significant (eigenvalue $>1$ ), which we call the GPI (Fig. 2.a), 
on the other hand, the governance indicator (GI) is determined by the first component in PCA that has an eigenvalue larger than 1.

We can calculate the GPI using the PCA technique for each country in our sample. The trend of this index for Southeast Asia is represented in Fig. 3.

According to Fig. 3, this index has improved with larger positive slopes for countries like Singapore and the Philippines. Furthermore, the GPI for the Philippines was higher than the GPI of Singapore in 2018, which shows the efficiency of plans or legislations towards a greener economy. Another critical point is that GPI trends have a turning point after each country issues related plans or regulations. Examples of this trend include Viet Nam in 2011 and 2012, when the country implemented the Viet Nam Climate Change Strategy in 2011 and the Viet Nam National Green Growth Strategy in 2012; Thailand in 2015 with its Attractive Energy Development Plan; Singapore in 1999 for the Environmental Protection \& Management Act; Indonesia in 2009 for Law No. 32 in its Management \& Protection of the Environment; Cambodia for its Law on Environmental Protection \& Natural Resource Management in 1996 and the National Policy on Green Growth in 2013; Myanmar in 2015 for its National Electrification Programme; Lao PDR in 2012 for with its Law on Environmental Protection; the Philippines for its Clean Air Act of 1999 and Environmental Education Act of 2008; and Malaysia with the Environmental Quality Act 1974, Regulations in 1989, and Efficient Management of Electrical Energy Regulations in 2008. The maturity of regulations aimed at greening the economy during time periods is a significant factor for a higher GPI. Countries like Singapore and the Philippines, who issued the related policy and legislations before the year 2000, have a higher GPI than other economies in Southeast Asia.

The average GPIs of Southeast Asian economies are higher than India, where the main challenges of electrification and energy transition from coal to green energy resources remain (Thomas et al. 2020). However, Southeast Asia is far behind the GPI levels of China, Japan, and the Republic of Korea (Fig. 4). Though China had a few failed policies in 2019 (Lin and Purra 2019), it had

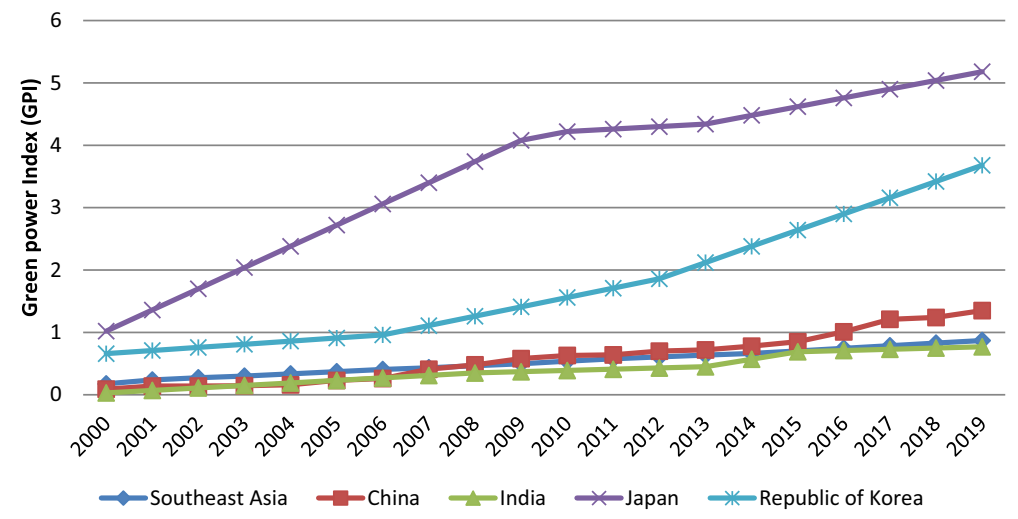

Fig. 4 Green power index, Southeast Asia, and other Asian countries, 2000-2019. Source: Authors' compilation from Minitab 20.2 
many successful attempts towards greening its economy with the Electric Power Law of the People's Republic of China in 1995; Renewable Energy Law in 2005; Electricity Sector Reforms in 2015; and the 13th Five Year Plan for Electricity, 2016-2020.

\subsection{Running preliminary tests}

Preliminary tests must be conducted prior to performing empirical estimations. For the first test, the cross-sectional dependency among variables is explored through three tests: Breusch-Pagan LM (Lagrange Multiplier), Pesaran Scaled LM and Pesaran CD (cross-sectional dependence). The results are in Table 2. We cannot accept the H0 (No cross-sectional dependency between countries) according to the probability values.

Due to the results of cross-sectional dependency, it is necessary to employ second-generation panel unit root tests to find the stationarity of series. Therefore, we employ first generation (Levin et al. 2002; Breitung 2001; Breitung and Das 2005; Im et al. 2003; and Fisher-ADF tests) and second-generation (the cross-sectionally augmented IPS test) panel unit root tests. The test results in Table 3 reveal that all series become stationary at the first difference or are integrated at I(1) or the first level of differences. This result highlights the need to implement a panel cointegration test.

To explore whether any long-run relationship exists among our model series, we carried out two panel cointegration tests, namely Pedroni (1997) and Westerlund (2007), with the null hypothesis of no cointegration among variables. As a firstgeneration test, the Pedroni cointegration test could not address structural breaks and cross-country correlations. Hence, this paper uses the Westerlund test based on structural dynamics as a second-generation test.

Table 4 represents the Pedroni cointegration test, which provides seven cointegration statistics based on homogeneity and heterogeneity assumptions. All the seven statistics (four panel statistics and three group panel statistics) have the null hypothesis in the absence of cointegration. The findings in Table 4 reveal that there exists cointegration among the series of our model.

The Kao cointegration test is also performed to ensure the reliability of the Pedroni cointegration test. As reported in Table 5, the null hypothesis of no

Table 2 Results of cross-sectional dependency tests

\begin{tabular}{lccc}
\hline & Breush-Pagan LM & Pesaran scaled LM & Pesaran CD \\
\hline Cross-sectional stat & 20.443 & 30.103 & 1.803 \\
$p$-value & $0.0277^{*}$ & $0.000^{*}$ & $0.081^{* *}$ \\
\hline
\end{tabular}

Source: Authors' compilation

*Significant levels at 5\%

**Significant levels at $1 \%$ 
Table 3 Results of panel unit root tests

\begin{tabular}{|c|c|c|c|c|c|}
\hline \multirow[t]{2}{*}{ Variable } & \multicolumn{4}{|c|}{ First generation panel unit root test } & \multirow{2}{*}{$\begin{array}{l}\text { Second generation } \\
\text { panel unit root test } \\
\text { CIPS }\end{array}$} \\
\hline & LLC & Breitung & IPS & Fisher-ADF & \\
\hline $\begin{array}{l}\text { GPI } \\
\mathrm{D}(\mathrm{GPI})\end{array}$ & $\begin{array}{l}-0.864 \\
-6.740^{*}\end{array}$ & $\begin{array}{l}3.658 \\
4.804 * *\end{array}$ & $\begin{array}{l}1.943 \\
-7.019^{*}\end{array}$ & $\begin{array}{l}5.684 \\
65.593 *\end{array}$ & $\begin{array}{l}-1.493 \\
-2.768 * *\end{array}$ \\
\hline $\begin{array}{l}\text { GDP } \\
\text { D(GDP) }\end{array}$ & $\begin{array}{l}-0.792 \\
-5.903 *\end{array}$ & $\begin{array}{l}3.485 \\
-2.800 *\end{array}$ & $\begin{array}{l}1.800 \\
-6.986^{*}\end{array}$ & $\begin{array}{l}3.447 \\
63.855^{*}\end{array}$ & $\begin{array}{l}-2.443 \\
-2.815^{*}\end{array}$ \\
\hline $\begin{array}{l}\text { FDI } \\
\text { D(FDI) }\end{array}$ & $\begin{array}{l}-1.015 \\
-3.650 *\end{array}$ & $\begin{array}{l}2.285 \\
-5.411 * *\end{array}$ & $\begin{array}{l}0.204 \\
-5.474 * *\end{array}$ & $\begin{array}{l}9.855 \\
50.185 *\end{array}$ & $\begin{array}{l}-0.704 \\
-2.954 *\end{array}$ \\
\hline $\begin{array}{l}\mathrm{RD} \\
\mathrm{D}(\mathrm{RD})\end{array}$ & $\begin{array}{l}-0.617 \\
-6.905 * *\end{array}$ & $\begin{array}{l}6.985 \\
-2.006^{* *}\end{array}$ & $\begin{array}{l}3.011 \\
-4.048 *\end{array}$ & $\begin{array}{l}3.940 \\
36.594 *\end{array}$ & $\begin{array}{l}-2.243 \\
-2.911 *\end{array}$ \\
\hline $\begin{array}{l}\text { TAR } \\
\text { D(TAR) }\end{array}$ & $\begin{array}{l}-0.416 \\
-4.019 *\end{array}$ & $\begin{array}{l}3.327 \\
4.500^{*}\end{array}$ & $\begin{array}{l}1.803 \\
-7.044^{*}\end{array}$ & $\begin{array}{l}9.118 \\
50.059 *\end{array}$ & $\begin{array}{l}-1.365 \\
-2.766^{*}\end{array}$ \\
\hline $\begin{array}{l}\text { PRIV } \\
\text { D(PRIV) }\end{array}$ & $\begin{array}{l}-0.1 \\
-6.549 *\end{array}$ & $\begin{array}{l}2.343 \\
-5.377 *\end{array}$ & $\begin{array}{l}1.803 \\
-6.899 *\end{array}$ & $\begin{array}{l}5.473 * \\
67.522 *\end{array}$ & $\begin{array}{l}-2.400 \\
-2.816^{*}\end{array}$ \\
\hline $\begin{array}{l}\text { GI } \\
\mathrm{D}(\mathrm{GI})\end{array}$ & $\begin{array}{l}-0.741 \\
-6.496 *\end{array}$ & $\begin{array}{l}3.793 \\
5.019 *\end{array}$ & $\begin{array}{l}3.057 \\
-4.053 *\end{array}$ & $\begin{array}{l}3.659 \\
61.700 * *\end{array}$ & $\begin{array}{l}-2.150 \\
-2.776^{*}\end{array}$ \\
\hline
\end{tabular}

Source: Authors' compilation

$F D I$ foreign direct investment, $G D P$ gross domestic product, $G I$ governance index, $G P I$ green power index, $P R I V$ privatisation, $R D$ research and development, TAR power tariff

*significant levels at $5 \%$

**significant levels at $1 \%$

Table 4 Panel cointegration test results, pedroni test

Table 5 Panel cointegration test results, Kao test

\begin{tabular}{lll}
\hline Trend assumption & $\begin{array}{l}\text { Deterministic } \\
\text { intercept ad trend }\end{array}$ & No deterministic trend \\
\hline Panel v-statistics & $-0.254(0.611)$ & $-0.411(0.670)$ \\
Panel-rho statistics & $-1.900(0.031)$ & $-0.215(0.438)$ \\
Panel PP-statistics & $-3.776(0.00)$ & $-1.100(0.151)$ \\
Panel ADF-statistics & $-3.019(0.00)$ & $-1.584(0.117)$ \\
Group rho-statistics & $-0.708(0.276)$ & $0.880(0.710)$ \\
Group PP-statistics & $-3.476(0.00)$ & $-0.432(0.375)$ \\
Group ADF-statistics & $3.294(0.00)$ & $-2.500(0.00)$ \\
\hline
\end{tabular}

Source: Authors' compilation

\begin{tabular}{llc}
\hline & t-stat & $p$-value \\
\hline ADF & -2.654 & 0.00 \\
\hline
\end{tabular}

Source: Authors' compilation

cointegration among series can be strongly rejected. Therefore, we can conclude that sustainable power markets and other variables in our model are moving together in the long run. 
Table 6 Panel cointegration test results, westerlund test

\begin{tabular}{llll}
\hline Statistics & Value & Prob & Robust prob \\
\hline $\mathrm{G}_{\mathrm{t}}$ & -4.694 & 0.00 & 0.00 \\
$\mathrm{G}_{\mathrm{a}}$ & -20.101 & 0.00 & 0.00 \\
$\mathrm{P}_{\mathrm{t}}$ & -7.868 & 0.00 & 0.00 \\
$\mathrm{P}_{\mathrm{a}}$ & -17.540 & 0.00 & .000 \\
\hline
\end{tabular}

Source: Authors' compilation

Considering the probability structural breaks during a time period, the Westerlund test - the second generation panel cointegration test-is employed, and its results in Table 6 depict that a long-run cointegration exists between variables.

Table 7 Pooled mean group findings, long-run coefficients
Table 8 Pooled mean group findings, short-run coefficients

\begin{tabular}{lll}
\hline Independent variable & Coefficient & t-stat \\
\hline Speed of adjustment & $-0.188^{* *}$ & -3.60 \\
GDP & $1.703^{*}$ & 4.76 \\
FDI & $0.795^{* *}$ & 3.94 \\
RD & $0.800^{*}$ & 4.91 \\
TAR & $-0.231^{* *}$ & -3.830 \\
PRIV & $0.065^{*}$ & 5.131 \\
GI & $0.139^{*}$ & 4.819 \\
\hline
\end{tabular}

Source: Authors' compilation

$G D P$ gross domestic product, $G I$ government index, $F D I$ foreign direct investment, $P R I V$ privatisation, $R D$ research and development, $T A R$ power tariff

* Significant levels at $5 \%$

**Significant levels at $1 \%$

\begin{tabular}{lcr}
\hline Independent variable & Coefficient & t-stat \\
\hline$\Delta$ GDP & $0.048^{*}$ & 6.303 \\
$\Delta$ FDI & $0.313^{*}$ & 4.794 \\
$\Delta$ RD & $0.011^{*}$ & 5.189 \\
$\Delta$ TAR & $-0.519 * *$ & -3.140 \\
$\Delta$ PRIV & $0.003 *$ & 6.103 \\
$\Delta$ GI & $0.261 *$ & 6.175 \\
\hline
\end{tabular}

Source: Authors' compilation

$\mathrm{GDP}=$ gross domestic product, $\mathrm{GI}=$ government index, FDI $=$ foreign direct investment, $\mathrm{PMG}=$ pooled mean group, $\mathrm{PRIV}=$ privatisation, $\mathrm{RD}=$ research and development, TAR $=$ power tariff

* Significant levels at $5 \%$

** Significant levels at $1 \%$ 


\subsection{Estimation findings}

To explore the signs and magnitudes of coefficients, the pooled mean group (PMG) estimator with the ARDL approach is performed to examine the impact of different variables on the Green Power Index as a proxy for the sustainable power market. Tables 7 and 8 represent the long- and short-run estimation results.

Regarding the long-run sustainable power market, the results in Table 7 proved that the impact of GDP is positive and statistically significant, meaning that a $1 \%$ increase in the economic size of Southeast Asian countries may lead to an increase in GPI nearly $1.7 \%$. The main reason for this positive impact is due to the expansion of green project financing and a better fiscal potential for governments under a positive growth rate, which was proved by earlier studies such as by Saufi et al. (2016). Moreover, the signs of FDI and R\&D are positive, highlighting the role of policies related to investment attraction and a higher share for $R \& D$ in annual country budgets in Southeast Asia. Interestingly, electricity tariffs have a negative impact on GPI. A $1 \%$ increase in power price may reduce GPIs by approximately $0.5 \%$ in these countries. In addition, we found that privatisation and governance quality on power market sustainability have positive impacts. A $1 \%$ increase in private investment in the power market may increase sustainability by about $0.06 \%$, while more efficient governance may increase it by $0.13 \%$. A highlighted point in the long-run estimations is that economic growth and governance indicators are two major influential factors on power market sustainability in our sample countries.

With regards to short-run estimated coefficients in Table 8, the signs of coefficients are similar to the long-run relationship. In other words, GDP, FDI, R\&D, privatisation, and governance indicators positively impact GPI, while any increase in electricity tariff deaccelerates power market sustainability. An interesting finding is that the signs of coefficients are similar in the short- and longrun, whereas the magnitudes of variables on power market sustainability are more robust in the long run. Further, in the short run, the impacts of FDI and governance indicators are more significant than those of other regressors.

The main reason for the larger magnitudes of coefficients in the long run is that government policies or any changes in macroeconomic variables must first go through the process of implementation and maturity in the short term before becoming more effective in the long run. Our finding of the larger magnitudes of coefficients in the long-run rather than short-run is in line with Braid (2003) and Dressler (2016), while it is in contrast with the findings of Galinato and Galinato (2013), who found larger impacts of variables in the short-run rather than longrun. In the case of Southeast Asian power markets, scholars believe that sustainability has a long-term process (Holden et al. 2014), and governments must implement reforms and policies to achieve sustainability in the long run. Therefore, any changes in macroeconomic variables, electricity tariffs, and governance are more influential in the long term, highlighting the need to prepare and establish a clear vision or strategic planning with long-run perspectives and missions to achieve power market sustainability. 
Table 9 Robustness check

\begin{tabular}{|c|c|c|c|c|}
\hline & \multicolumn{2}{|c|}{ MG estimator } & \multicolumn{2}{|c|}{ DFE estimator } \\
\hline & Coefficient & t-stat & Coefficient & t-stat \\
\hline \multicolumn{5}{|l|}{ Long-run estimation } \\
\hline Speed of adjustment & $-0.014 * *$ & -2.980 & $-0.131 *$ & -5.492 \\
\hline GDP & $0.672 * *$ & 3.101 & $\mathbf{0 . 0 3 1} * *$ & 2.850 \\
\hline FDI & $0.026 *$ & 5.185 & $0.024 *$ & 4.157 \\
\hline $\mathrm{RD}$ & $0.043 *$ & 4.695 & 0.019* & 3.804 \\
\hline TAR & $-0.011 * *$ & -3.414 & $-0.002 * *$ & 2.933 \\
\hline PRIV & 0.013* & 4.906 & 0.019* & 5.094 \\
\hline GI & $0.213^{*}$ & 7.594 & $0.025 *$ & 4.731 \\
\hline \multicolumn{5}{|l|}{ Short-run estimation } \\
\hline$\Delta \mathrm{GDP}$ & $0.483 *$ & 5.193 & 0.029* & 4.584 \\
\hline$\Delta \mathrm{FDI}$ & $0.258 * *$ & 2.685 & 0.018* & 5.696 \\
\hline$\Delta \mathrm{RD}$ & $0.194 *$ & 4.937 & $0.014 * *$ & 2.388 \\
\hline$\Delta \mathrm{TAR}$ & $-0.014 * *$ & -2.994 & $-0.000 *$ & 6.110 \\
\hline$\Delta$ PRIV & $0.009 *$ & 5.685 & $0.015 *$ & 4.770 \\
\hline$\Delta \mathrm{GI}$ & 0.118* & 5.145 & $0.017 * *$ & 3.19 \\
\hline
\end{tabular}

* significant levels at $5 \%$

** significant levels at $1 \%$

$\mathrm{GDP}=$ gross domestic product, $\mathrm{GI}=$ government index, FDI $=$ foreign direct investment, $\mathrm{PRIV}=$ privatisation, $\mathrm{RD}=$ research and development, TAR $=$ power tariff

Source: Authors' compilation

\subsection{Robustness check}

To carry out an appropriate robustness check to ensure estimated coefficients are reliable, two other estimators of MG and DFE are employed to find out the sensitivity of empirical results to the alternative ARDL panel estimators. The findings of these two estimators are reported in Table 9.

The results from the robustness check prove that all the variables of our model retain similar signs estimated through the PMG estimator. This validates the positive impacts of GDP, FDI, power market privatisation, and governance on power market sustainability while proving that any increase in electricity tariff reduces the sustainability of the power market in both short- and long-run. Further, estimations from both MG and DFE revealed that impacts of variables towards a sustainable power market in the long-term are larger than impacts in the short term, which is in line with our earlier estimated coefficients by PMG. 


\section{Conclusions and policy implications}

The debatable topic of power market reform in Southeast Asia, where countries seek a more competitive operation, a sustainable market, and private participation, is considered in this research. We gathered annual data of different variables classified into macroeconomic variables, general governance, power market governance, and power price in 2000-2019 for countries in the region. The method of analysis of these raw annual data was the ARDL panel technique through the PMG estimator and two other estimators of MG and DFE for robustness check. Further, for the first time, a multidimensional power green index as a proxy for sustainable power market is proposed in this study and was constructed through the PCA technique from three different variables: the electrification ratio, share of renewable energy in the total power generation, and energy-related carbon emission level. We also introduced the general governance index, which was generated by mixing three variables-political stability, regulatory quality, and government effectiveness-through the PCA technique.

The findings for a relationship between the selected independent variables and the Green Power Index (GPI), which we proposed for the first time in this paper, revealed that Southeast Asian governments can consider economic growth, improved FDI inflow, increased R\&D budget, improved governance quality, and power market privatisation as appropriate accelerators towards power market sustainability in the short- and long-run, while any increase in electricity price may reduce the pace of achieving sustainability in the power market in both the short and long time periods. The findings also depicted that the impacts of variables on power market sustainability are larger in the long run than the short run, highlighting the need for governments to issue strategy plans and roadmaps with clear visions and missions in the power market sustainability.

Findings from this research lead to policy implications, not just for countries in Southeast Asia, but also for other developing nations in the world. The significant policy recommendation could help governments adopt green energy policies towards universal electrification goals. The major practical policy implications are as follows:

i. Since economic size, or GDP, is a major influential factor for reaching power market sustainability, Southeast Asian countries need to adapt to new situations and health protocols resulting from COVID-19 to rebuild their national economies. Using fresh ideas like 'build back better' proposed by Moore and Collins (2021) or tourism recovery discussed by Scarlett (2021) can be a helpful tool for the economic recovery in Southeast Asia.

ii. The flow of FDI into Southeast Asian economies has a positive and significant impact on achieving sustainable power markets, highlighting the need for reforms in FDI regulations to absorb foreign investment. Boosting bilateral investments and partnerships among countries in this region and other economic powers in Asia and other regions is highly recommended. In addition, 
expanding special economic zones (SEZs) could be a good tool for economies to attract foreign capital. Earlier studies by Wahyuni et al. (2013) and Teangsompong and Sirisunhirun (2018) proved the vital role of SEZs in attracting FDI in Southeast Asia.

iii. Since an increase in the price of electricity harms achieving a sustainable power market in Southeast Asia, a recommendation is for governments to implement an electricity tariff classification (ETC) to help vulnerable, low-income electricity customers. It would be a good policy to provide the best electricity price lists to households, firms, and industries. Malaysia has successfully carried out such an approach where the Malaysian multinational electricity company, Tenega Nasional Berhad, used the ETC approach, especially during the COVID-19 pandemic. In addition, since $1^{\text {st }}$ December 2021, Malaysia has launched the Green Electricity Tariff (GBT) to improve the consumption of green electricity generated by solar and hydropower plants in different aspects of the national economy. Other southeast economies can study and use the experiences of Malaysia in the fields of ETC and GBT.

iv. Southeast Asian governments should increase the pace of privatisation in the power market through different policies and instruments. Governments should provide financial support and temporary tax exemptions. Governments need to grant private investors more autonomy and incentives for participation in the power markets.

v. One of the challenging issues of countries during the outbreak of COVID-19 is the reachability of green development and green growth. According to this research, power market sustainability can be addressed as a successful wing of green recovery in the post-COVID-19 in Southeast Asian economies and other nations in the world. There is a need to move towards green revitalization by implementing policies such as sustainable electricity generation. In addition to economic prosperity, environmental and climate change prevention goals could be achieved.

Notwithstanding new insights from this research on power market sustainability in Southeast Asia, there are still gaps and areas for further study. For example, the measure of impacts of different variables on the Southeast Asian power market in the post-COVID era is still debatable. Moreover, future research should also capture the impacts of other variables — such as bilateral exchange rate, electricity price-cost margins, cross-subsidy level, and income inequality-on power market sustainability in Southeast Asia.

Acknowledgements Authors are grateful to the Economic Research Institute for ASEAN and East Asia (ERIA) for supporting this study. The paper is the results of the research project on: "Electricity Market Reforms in ASEAN, India, and China (FY2021-2022). The authors are grateful to Mr. Taizo Hara, Director General for Research and Policy Design, ERIA, and Prof. Fukunari Kimura, Chief Economist, ERIA, and all the esteemed participants of the aforementioned project' working groups for their comments. Their precious comments helped us revise the paper and prepare the current version. 
Funding This study was financially supported by the Economic Research Institute for ASEAN and East Asia (ERIA).

\section{Declarations}

Conflict of interest The authors declare no conflict of interest.

Ethical approval Not applicable.

\section{References}

Akrami A, Doostizadeh M, Aminifar F (2019) Power system flexibility: an overview of emergence to evolution. J Mod Power Syst Clean Energy 7:987-1007

Anh TC, Rasoulinezhad E (2021a) Energy efficiency financing and the role of green bond: policies for post-Covid period. China Fin Rev Int, Vol. ahead-of-print No. ahead-of-print. https://doi.org/10. 1108/CFRI-03-2021a-0052

Balza L, Jimenez R, Mercado J (2013) 'Privatisation, institutional reform, and performance in the Latin American Electricity Sector'. IDB Technical Note. No. TN-599. https://publications.iadb.org/publi cations/english/document/Privatisation-Institutional-Reform-and-Performance-in-the-Latin-Ameri can-Electricity-Sector.pdf. (Accessed 01 May 2021)

Besant-Jones JE (2006) Reforming power markets in developing countries: What have we learned? Energy and Mining Sector Board Discussion Paper, No. 19, Washington, DC: World Bank. http:// documents1.worldbank.org/curated/en/483161468313819882/pdf/380170REPLACEMENT0En ergy19.pdf. (Accessed 20 April.2021)

Braid R (2003) A three-input model of the spatial effects of a central-city wage tax. J Urban Econ 54(1):89-109

Brown D, Eckert A, Eckert H (2017) Electricity markets in transition: market distortions associated with retail price controls. Electr J 30(5):32-37

Breitung J (2001) The local power of some unit root tests for panel data. Nonstationary Panels, Panel Cointegration, and Dynamic Panels, Emerald Group Publishing Limited, pp 161-77

Cieplinski A, D’Alessandro S, Marghella F (2021) Assessing the renewable energy policy paradox: a scenario analysis for the Italian electricity market. Renew Sustain Energy Rev 142:110838. https://doi. org/10.1016/j.rser.2021.110838

Defeuilley C (2019) Energy transition and the future(s) of the electricity sector. Utilities Policy 57:97-105

Delina L (2021) Promises and Pitfalls of China-Southeast Asia energy connectivity. Energy Strategy Rev. 33. https://doi.org/10.1016/j.esr.2020.100574. (Accessed 12 March 2021)

Dodd T, Rai A, Caught K (2020) Electricity markets in flux: the importance of a just transition. Electr J 33(9). https://doi.org/10.1016/j.tej.2020.106835 (Accessed 13 March 2021)

Dressler S (2016) A long-run, short-run and politico-economic analysis of the welfare costs of inflation. J Macroecon 47(B), pp 255-69

Dussan M (1996) Electric power sector reform In Latin America and the Caribbean. IDB Working Paper Series. IFM-104. https://publications.iadb.org/publications/english/document/Electric-Power-Sector-Reform-in-Latin-America-and-the-Caribbean.pdf. (Accessed 13 March 2021)

Galinator G, Galinator S (2013) The short-run and long-run effects of corruption control and political stability on forest cover. Ecol Econ 89:153-161

Guo H, Davidson M, Chen Q, Zhang D, Jiang N, Xia Q, Kang C, Zhang X (2020) Power market reform in China: motivations, progress and recommendations. Energy Policy. https://doi.org/10.1016/j. enpol.2020.111717

Hao W, Abbas Q, Ahmad I, Alharthi M, Hanif I, Taghizadeh-Hesary F (2021) Institutional efficiency and utility reform performance: an evidence from electricity performance in South and East Asia. Econ Anal Policy 72:549-561. https://doi.org/10.1016/j.eap.2021.09.013

Holden E, Linnerud K, Banister D (2014) Sustainable development: our common future revisited. Glob Environ Chang 26:130-139 
International Energy Agency (2019) Southeast Asia energy outlook 2019: comprehensive review of a region on the rise. IEA Publications, Paris

International Energy Agency (2020) 2020 electricity market report-december 2020. https://www.iea.org/ reports/electricity-market-report-december-2020/2020-regional-focus-southeast-asia. (Accessed 27 April 2021)

Im KS, Pesaran M, Shin Y (2003) Testing for unit roots in heterogeneous panels. J Economet 115:53-74

Kao C (1999) Spurios regression and residual-based tests for cointegration in panel data. J Economet 90:1-44

Kundu G, Mishra B (2011) Impact of reform and privatisation on consumers: a case study of power sector reform in Orissa, India. Energy Policy 39(6):3537-3549

Lau L, Ng C, Cheah S, Choong C (2019) Chapter 9: panel data analysis (stationarity, cointegration and causality). In: Ozan B, Ozturk I (eds), Environmental Kuznets curve, pp 101-13, Turkey: Academic Press, https://doi.org/10.1016/C2018-0-00657-X. (Accessed 13 March 2021)

Levin A, Lin C, Chu C (2002) Unit root tests in panel data: asymptotic and finite-sample properties. J Economet 108:1-24

Lin K, Purra M (2019) Transforming China's electricity sector: politics of institutional change and regulation, 124, pp 401-10

Mier M, Weissbart C (2020) Power markets in transition: decarbonization, energy efficiency, and shortterm demand response. Energy Econ. https://doi.org/10.1016/j.eneco.2019.104644

Mohsin M, Hanif I, Taghizadeh-Hesary F, Abbas Q, Iqbal W (2021) Nexus between energy efficiency and electricity reforms: a DEA-based way forward for clean power development. Energy Policy 149:112052. https://doi.org/10.1016/j.enpol.2020.112052

Moore H, Collins H (2021) Rebuilding the post-Covid-19 economy through an industrial strategy that secures livelihoods. Soc Sci Human Open 3(1). https://doi.org/10.1016/j.ssaho.2021.100113. (Accessed 10 March 2021)

Nasr Esfahani A, Moghaddam N, Maleki A, Nazemi A (2021) The knowledge map of energy security. Energy Rep 7:3570-3589

Nelson J (2020) 'Australia's National electricity market: financing the transition. Electr J 33(9). https:// doi.org/10.1016/j.tej.2020.106834. (Accessed 10 March 2021)

Norouzi N, Rubens G, Enevoldsen P, Forough AB (2020) The impact of COVID-19 on the electricity sector in spain: an econometric approach based on prices. Int J Energy Res 45(4):6320-6332

Pedroni P (1999) Critical values for cointegration tests in heterogeneous panels with multiple regressors. Oxford Bull Econ Stat 61:653-670

Pesaran MH (2007) A simple panel unit root test in the presence of cross- section dependence. J Appl Economet 22:265-312

Pesaran MH, Smith R (1995) Estimating long-run relationships from dynamic heterogeneous panels. J Economet 68:79-113

Pineau P (2002) Electricity sector reform in cameroon: Is privatisation the solution? Energy Policy 30(11-12):999-1012

Pollitt M (2019) The European single market in electricity: an economic assessment. Rev Ind Organ 55:63-87

Poudineh R, Sen A, Fattouh B (2020) An integrated approach to electricity sector reforms in the resource rich economies of the MENA. Energy Policy 138:111236. https://doi.org/10.1016/j.enpol.2019. 111236

Sarangi GK, Mishra A, Chang Y, Taghizadeh-Hesary F (2019) Indian electricity sector, energy security and sustainability: an empirical assessment. Energy Policy 135(110964). https://doi.org/10.1016/j. enpol.2019.110964. (Accessed 10 March 2021)

Saufi N, Daud S, Hassan H (2016) Green growth and corporate sustainability performance. Procedia Econ Fin 35:374-378

Scarlett H (2021) Tourism recovery and the economic impact: a panel assessment. Res Glob. https://doi. org/10.1016/j.resglo.2021.100044

Senerdem E, Akkemik K (2020) Evaluation of the reform in the Turkish electricity sector: a CGE analysis. Int J Econ Policy Stud 14:389-419

Sharma D (2005) Electricity reforms in the ASEAN: a panoramic discourse. Econ Pol Wkly 40(50):5318-5326

Sirin S, Erdogen F (2013) R\&D Expenditures in liberalisation of electricity markets: the case of Turkey. Renew Sustain Energy Rev 24:491-498 
Smolovic J, Muhadinovic M, Radonjic M, Duraskovic J (2020) How does renewable energy consumption affect economic growth in the traditional and new member States of the European Union? Energy Rep 6(6):505-513

Sorknas PH, Skov LI, Sjorup S, Skytte K, Morthorst P, Fausto F (2020) Smart energy markets-future electricity, gas, and heating markets. Renew Sustain Energy Rev 119:109655. https://doi.org/10. 1016/j.rser.2019.109655

Taghizadeh-Hesary F, Yoshino N (2019) The way to induce private participation in green finance and investment. Financ Res Lett 31:98-103. https://doi.org/10.1016/j.frl.2019.04.016

Taghizadeh-Hesary F, Yoshino N, Rasoulinezhad E, Rimaud C (2021) Power purchase agreements with incremental tariffs in local currency: an innovative green finance tool. Glob Financ J 50:100666. https://doi.org/10.1016/j.gfj.2021.100666

Teangsompong T, Sirisunhirun S (2018) Multi-level structural equation modeling for city development based on the expectations of the local population in a special border economic Zone in Western Thailand. Kasetsart J Soc Sci 39(3):534-541

Thomas D, Harish S, Kennedy R, Urpelainen J (2020) The effects of rural electrification in India: an instrumental variable approach at the household level. J Dev Econ. https://doi.org/10.1016/j.jdeve co. 2020.102520

Tsao Y, Vu T, Lu J (2021) Pricing, capacity and financing policies for investment of renewable energy generations. Appl Energy 303:117664. https://doi.org/10.1016/j.apenergy.2021.117664

Tsay I, Chen P (2019) A dual market structure design for the reform of an independent power grid system-the case of Taiwan. Energy Rep 5:1603-1615

Tran QH (2021b) The impact of green finance, economic growth and energy usage on CO2 emission in Vietnam-a multivariate time series analysis. China Finance Rev Int. Vol. ahead-of-print No. ahead-of-print. https://doi.org/10.1108/CFRI-03-2021b-0049

Urpelainen J, Yang J (2019) Global patterns of power sector reform, 1982-2013. Energ Strat Rev 23:152-162

Weatherby C (2020) Renewable Energy in Southeast Asia. NBER Working Paper No.89. https://www. nbr.org/publication/renewable-energy-in-southeast-asia/. (Accessed 20 April 2021)

Westerlund J (2007) Testing for error correction in panel data. Oxford Bull Econ Stat 69:709-748

Xu J, Guo Y (2017) The review of the electric power market reform on electricity sale side. In: IEEE 2nd information technology, networking, electronic and automation control conference, pp 613-17. https://ieeexplore.ieee.org/document/8284805. (Accessed 10 March 2021)

Xuegong S, Liyan G, Zhen Z (2013) Market entry barriers for foreign direct investment and private investors: lessons from China's electricity market. Energ Strat Rev 2(2):169-175

Yin J, Yan Q, Lei K, Balezentis T, Streimikiene D (2019) Economic and efficiency analysis of china electricity market reform using computable general equilibrium model. Sustainability 11:350. https:// www.mdpi.com/2071-1050/11/2/350. (Accessed 10 March 2021)

Wahyuni S, Astuti E, Utari K (2013) Critical outlook at special economic zone in Asia: a comparison between Indonesia, Malaysia, Thailand and China. J Indonesian Econ Business 28(3):336-346

Wang F, Yin H, Li S (2010) China's renewable energy policy: commitments and challenges. Energy Policy 38(4): 1872-1878

Zheng W (2021) Effects of China's market-oriented economic reform, fdi inflows on electricity intensity. Energy. https://doi.org/10.1016/j.energy.2021.119934

Zsiboracs H, Baranyai N, Zentko L, Moracs A, Pocs I, Mate K, Pinter G (2020) Electricity market challenges of photovoltaic and energy storage technologies in the European Union: regulatory challenges and responses. Appl Sci 10(4). https://www.mdpi.com/2076-3417/10/4/1472. (Accessed 10 March 2021)

Publisher's Note Springer Nature remains neutral with regard to jurisdictional claims in published maps and institutional affiliations. 